\title{
POLITIK HUKUM PIDANA MELALUI SARANA NON PENAL DALAM MENANGGULANGI KEJAHATAN DI BIDANG PENDIDIKAN
}

\author{
Kartono \\ Fakultas Hukum Universitas pamulang \\ E-mail: dosen001490@unpam.ac.id
}

\begin{abstract}
ABSTRAK
Politik Hukum Pidana Melalui Sarana Non Penal Dalam Menanggulangi Tindak Pidana Di Bidang Pendidikan. Tindak pidana yang menjadi fokus dalam penelitian ini adalah tindak pidana yang dilakukan guru dalam melaksanakan tugas/profesi keguruannya. Penelitian ini merupakan penelitian yuridisnormatif. Data-data yang relevan dengan penelitian ini lebih difokuskan pada data sekunder yang diperoleh melalui studi literatur (literate studi), yang selanjutnya dianalisis secara deskriptif-analitis. Dari penelitian ini diperoleh hasil bahwa: pertama, jenis-jenis tindak pidana di bidang pendidikan secara umum, dan tindak pidana yang dilakukan guru dalam melaksanakan tugas/profesinya. Kedua, Kebijakan hukum pidana saat ini yang digunakan terhadap tindak pidana yang dilakukan guru dalam melaksanakan tugasnya, terbatas pada KUHP dan Undang-undang Nomor 35 Tahun 2014 tentang perlindungan anak, yang dikaitkan dengan tindak pidana murni dan tindak pidana refleksi kedisiplinan. Ketiga, upaya penanggulangan kejahatan melalui sarana non penal. Usaha non penal dalam menanggulangi kejahatan sangat berkaitan erat dengan usaha penal. Upaya non penal ini dengan sendirinya akan sangat menunjang penyelenggaraan peradilan pidana dalam mencapai tujuannya. Pencegahan atau menanggulangi kejahatan harus dilakukan pendekatan integral yaitu antara sarana penal dan non penal
\end{abstract}

Kata Kunci : Politik Hukum Pidana, Non Penal, Pendidikan

\section{ABSTRACT}

Criminal Law Politics Through Non-Penal Facility In Overcoming Criminal Acts In The Field of Education. Criminal acts that became the focus in this research is the criminal acts committed by teachers in carrying out the task I profession teacher. This research is a juridical-normative research. The data relevant to this research is more focused on secondary data obtained through literature study (literate study), which then analyzed descriptivelyanalytical. From this research, it is found that: first, the types of criminal acts in the field of education in general, and the criminal acts committed by teachers in carrying out their duties / profession. Secondly, the current criminal justice policy used against criminal offenses committed by teachers in performing their duties is limited to the Criminal Code and Law No. 35 of 2014 on child protection, which is linked to pure crime and the disciplinary act of disciplinary reflection. Third, crime prevention efforts through nonpenal means. Non penal efforts in tackling crime are closely related to penal businesses. This non-penalty effort by itself will greatly support the 
implementation of criminal justice in achieving its objectives. Prevention or tackling crime should be an integral approach between penal and non penal means.

Keywords : Criminal Law Politics, Non Penal, Education Crime

\section{Pendahuluan}

Pidana merupakan sanksi bagi para pelaku tindak pidana bagi mereka yang telah melanggar delik yang diatur dalam Kitab Undang-Undang Hukum Pidana (KUHP), kekakuan hukum pidana dalam menanggulangi kejahatan tidak memberikan dampak yang signifikan dimana masih terjadinya pengulangan akan kejahatan yang telah di hukum oleh hukum pidana. Dewasa ini hukum pidana selalu menjadi primum remedium dalam menyelesaikan persoalanpersoalan kejahatan, padahal masih, banyak solusi-solusi lain yang dapat ditempuh dalam menyelesaikan permasalahan pidana termasuk persoalanan kejahatan yang dilakukan dalam pendidikan sehingga hukum pidana tidak dipergunakan secara boros karena pada prinsipnya hukum pidana sebagai ultimum remedium.

Mengingat pendidikan merupakan salah satu instrumen pokok bagi sustainabledevelopment (pembangunan berkelanjutan) dari suatu negara, dan mengingat penyimpangan terhadap dunia pendidikan yang dilakukan profesi guru bukan hanya pelanggaran hukum belaka,namun dapat dimungkinkan sebagai pelanggaran etikaatau moral.

Etika itu lebih luas dari pada hukum yang lebih sempit. Menurut Jimly Asshiddiqie: "setiap pelanggaran hukum dapat dikatakan juga merupakan pelanggaran etika, tetapi sesuatu yang melanggar etika belum tentu melanggar hukum."

Fenomena kejahatan sebagai salah satu bentuk dari perilaku menyimpang selalu ada dan melekat pada tiap bentuk masyarakat. Menurut Benedict S. Alper "kejahatan merupakan the oldest sosial problem". 2 Perilaku menyimpang merupakan suatu ancaman yang nyata atau ancaman terhadap norma-norma sosial yang mendasari kehidupan atau keteraturan sosial. Dalam duni apendidikan sekali pun perilaku menyimpang dapat terjadi, dan guru seperti halnya manusia yang lain mempunyai potensi yang sama untuk melakukan perilaku menyimpang tersebut. Oleh karena itu, sebagai bentuk masalah social bahkan masalah kemanusiaan maka perilaku menyimpang (kejahatan) tersebut perlu segera ditanggulangi, tidak terkecuali perilaku menyimpang yang terjadi dalam duniapendidikan. hlm.xii.

${ }^{1}$ JimlyAsshiddiqie, Peradilan Etik dan Etika Konstitusi, Sinar Grafika, Jakarta, 2014,

${ }^{2}$ Barda Nawawi Arief, Kebijakan Legislatif Dalam Penanggulangan Kejahatan Dengan Pidana Penjara,Badan Penerbit UNDIP, Semarang 1996, hlm. 11. 
Menurut Ridwan Halim, bentuk-bentuk penyimpangan yang biasanya terjadidalam dunia pendidikan dapat berupa:

1. Penekanan nilai prestasi murid dalam segala bentuk dan tujuan;

2. berbagai bentuk pungutan liar (pungli);

3. berbagai bentuk penipuan dan pengakuan palsu yang dilakukan oleh oknum yangtidak bertanggung jawab;

4. pencurian karangan dalam bentuk apapun dalam jumlah berapa pun yang disertaidengan penipuan dan pengakuan palsu (plagiat);

5. berbagai bentuk pelaksanaan Pendidikan yang salah, baik yang disengaja maupunyang tidak disengaja;

6. dan, sebagai tambahan adalah perbuatan-perbuatan yang merupakan tindak pidanaumum (seperti yang diatur dalam KUHP dan Undangundang di luar KUHP) yangdilakukan terhadap guru/tenaga pendidik, lembaga Pendidikan, danmurid/mahasiswa oleh pihak penyelenggara Pendidikan itu sendiri, maupunmasyarakat luas, seperti: korupsi terhadap dana-dana Pendidikan, berbagai bentukkekerasan, perbuatan asusila serta berbagai bentuk pencemaran ataupun penghinaan. ${ }^{3}$

Dalam menjalankan profesinya sebagai guru, tidak jarang perilaku atau kebijaksanaan seorang guru dirasakan oleh anak didik atau pihak lain sebagai perbuatan yang tidak menyenangkan, merugikan, atau dipandang sangat memberatkan. Bentuk perilaku guru yang dinilai oleh masyarakat sebagai ketidakprofesionalannya guru adalah kekerasan kepada siswa pada saat pengajaran di sekolah. Perilaku ini menjadi sangat disoroti tidak saja oleh masyarakat, tetapi juga sejumlah pihak, seperti lembaga perlindungan anak. Kekerasan itu tidak saja berupa fisik, tetapi simbolik, atau kedua-duanya dilakukan secara bersamaan.

Jika perilaku etika guru dikaitkan dengan guru sebagai tenaga professional yang sangat mengandalkan kepercayaan publik (public trust). Maka harus pula sidasari bahwa pendekatan hukum seringkali terbukti kontra prodiktif dengan menjaga kepercayaan pubik itu. Cara bekerjanya sistem penegakan hukum yang bertele-tele sering sekali berdampak buruk kepada citra dan kepercayaan publik terhadap guru. Karena, sebelum suatu tuduhan pelanggaran hukum dapat dibuktikan secara tuntas di pengadilan, citra institusi atau lembaga tempat yang bersangkutan bekerja sudah hancur lebih dulu di mata publik. Menurut Jimly Asshiddiqie : "Pembinaan dan pengendalian perilaku ideal terhadap orang-orang yang duduk dalam jabatanjabatan publik, lebih baik dilakukan melalui sistemetika atau setidak tidaknya melalui sistem etika lebih dahulu, baru dengan menggunakan sistem hukum". 4

${ }^{3}$ Ridwan Halim, Tindak Pidana Pendidikan Dalam Asas-Asas Hukum Pidana Indonesia, Ghalia Indonesia, 1986, Jakarta hlm 32 - 46.

${ }^{4}$ Ibid, hlm. xiii 


\section{Permasalahan}

Dilihat dari aspek hukum pidana, mungkin saja perbuatan/tindakan guru yang dikemukakan di atas, secara formal bersifat melawan hukum atau merupakan tindak pidana. Misalnya, dapat dikategorikan sebagai bentuk “penghinaan” (Pasal 310/315 KUHP); “perampasan kemerdekaan” (Pasal 333334 KUHP); “perbuatan tidak menyenangkan” (Pasal 335 KUHP), atau sebagai bentuk "penganiayaan” (Pasal 351 danPasal 352 KUHP).

Meskipun demikian, penetrasi hukum pidana dalam ranah pendidikan untuk beberapa kalangan masih dianggap sebagai sesuatu yang berlebihan. Dikatakan demikian karena hukum pidana dan pendidikan mempunyai sifat dan pendekatan yang berbeda dalam menanggulangi suatu penyimpangan. Hukum pidana bersifat keras dan tegas karena dilengkapi dengan sanksi pidana dalam penerapannya, sedangkan pendidikan bersifat lunak karena lebih mengedepankan pendekatan kognitif, afektif dan psikomotorik secara integral dalam pembinaannya.

Dalam hukum pidana tidak selalu orang yang secara formal telah melakukan perbuatan melawan hukum (tindak pidana) harus dipertanggungjawabkan atau dipidana. Menurut Barda Nawawi Arief: "dalam hukum pidana ada "Alasan Penghapus Pidana (APP) berupa "alas an pembenar" (yang menghapuskan sifat melawan hukumnya perbuatan) dan "alasan pemaaf" (menghapuskan kesalahan). APP dapat berdasarkan ketentuan undang-undang (APP formil) dan berdasarkan ketentuan hukum tidak tertulis (APP materiel)." 5

Dalam APP materiel dikenal antara lain dua asas yang sangat popular dan fundamental, yaitu:

a. Asas "tidak adanya sifat melawan hukum secara materiel (dikenal dengan asas"materiel eweder rechtelijkheid"atau asas AVAW "Afwezigheid van Alle Materiele Weder rechtelijkheid").

b. Asas "tidak adanya kesalahan sama sekali" (dikenal dengan asas "green strafzonderschuld" atau asa AVAS - "Afwezigheidvan Alle Schuld").

Perbuatan melawan hukum yang dilakukan oleh guru ternyata tidak selalu diselesaikan melalui jalan penal akan tetapi bisa diselesaikan melalui jalan Non penal, maka terdapat beberapa permasalahan yang layak dikedepankan yaitu Pertama Bagaimana peranan penggunaan sarana non penal dalam menanggulangi kejahatan di bidang pendidikan ? Kedua, Bagaimana Efektifitas sarana non penal dalam menanggulangi kejahatan dibidang pendidikan ?

\footnotetext{
${ }^{5}$ Barda Nawawi Arief, Pembaruan Hukum Pidana dalam Perspektif Kajian Perbandingan" PT Citra Aditya Bakti, Bandung, 2011, hlm. 74

${ }^{6}$ lbid
} 


\section{Metode Penelitian}

Penelitian ini merupakan sarana pokok dalam pengembangan ilmu pengetahuan. Hal ini disebabkan oleh karena penelitian bertujuan untuk mengungkapkan kebenaran secara sistematis, metodologis, dan konsisten. ${ }^{7}$ Keberadaan setiap metodologi di dalam setiap penelitian dan pengembangan ilmu pengetahuan adalah merupakan suatu unsur yang mutlak harus ada. ${ }^{8}$ Metode penelitian yang digunakan penelitian ini adalah yuridis normatif.

\section{Pembahasan}

Penetrasi hukum pidana dalam ranah pendidikan untuk beberapa kalangan masih dianggap sebagai sesuatu yang berlebihan. Dikatakan demikian karena hukum pidana dan pendidikan mempunyai sifat dan pendekatan yang berbeda dalam menanggulangi suatu penyimpangan. Hukum pidana bersifat keras dan tegas karena dilengkapi dengan sanksi pidana dalam penerapannya, sedangkan pendidikan bersifat lunak karena lebih mengedepankan pendekatan kognitif, afektif dan psikomotorik secara integral dalam pembinaannya. Melihat akselerasi perkembangan masyarakat dewasa ini, pada dasarnya fungsi hukum pidana lebih luas. Artinya, hukum pidana dapat difungsikan atau dilibatkan dalam menanggulangi berbagai bentuk penyimpangan yang terjadi pada setiap aspek kehidupan masyarakat, termasuk penyimpangan pada aspek pendidikan.

Hukum senantiasa hidup dalam masyarakat. Keduanya hampir tidak dapat dipisahkan bahkan terjalin hubungan timbal balik. Hal ini sesuai dengan adagium yang berlaku universal ubi societas, ibi ius, yang artinya: dimana ada masyarakat, maka di sanalah hukum akan ada. Hukum lahir sebagai hasil konstruksi sosial masyarakat dan masyarakat pula yang akan menggunakan hukum dengan tujuan untuk mewujudkan ketertiban dan keadilan yang dikehendaki. Menurut Soerjono Soekanto, "Hukum setidaknya mempunyai 3 (tiga) peranan utama dalam masyarakat, sebagai berikut :
a. Sebagai sarana pengendalian sosial;
b. Sebagai sarana untuk memperlancar proses interaksi sosial;
c. Sebagai sarana untuk menciptakan keadaan tertentu. ${ }^{9}$

Hukum pidana merupakan bagian dari sistem hukum atau sistem normanorma. Dibandingkan hukum publik lainnya, hukum pidana memang mempunyai keunikan tersendiri, yakni adanya sanksi pidana sebagai sanksi negatif yang diterapkan terhadap pelanggaran dan kejahatan. Menurut Utrecht, sebagaimana dikutip Teguh Prasetyo mengatakan bahwa: "Hukum Pidana mempunyai kedudukan istimewa yang harus diberi tempat tersendiri di

\footnotetext{
${ }^{7}$ Soerjono Soekanto dan Sry Mamuji, Penelitian Hukum Normatif, cet 4,PT. Raja Grapindo Persada, Jakarta, 1994, hal. 1.

${ }^{8}$ Soerjono Soekanto, Pengantar Penelitian Hukum, cet.4, Universitas Indonesia, Jakarta,1986, hal. 12.

${ }^{9}$ Soerjono Soekanto, Pengantar Penelitian Hukum, UI Press, Jakarta, 1986, hlm. 34.
} 
luar kelompok hukum publik dan hukum privat". ${ }^{10}$ Utrecht melihat hukum pidana sebagai suatu sistem hukum sanksi (bijzonder sanctie recht)". Sanksi pidana yang bersifat tegas dan keras serta identik dengan penderitaan (pemberian nestapa) ini yang sering menjadi pertimbangan untuk tidak menggunakan hukum pidana dalam rangka melindungi kepentingankepentingan privat ataupun kepentingan publik yang mengandung nilai-nilai pembinaan di dalamnya, termasuk kepentingan pendidikan. Pada dasarnya eksistensi hukum pidana mengandung fungsi ganda (double function), yakni melindungi kepentingan yang diselenggarakan oleh peraturan-peraturan hukum privat maupun hukum publik. Sanksi istimewa yang melekat pada hukum pidana hanya merupakan sarana untuk melindungi kedua macam kepentingan tersebut. Sebagai salah satu sarana perlindungan, hukum pidana tidak serta merta digunakan begitu saja untuk menanggulangi setiap bentuk penyimpangan. Hukum pidana dalam hal ini bersifat ultimum remedium, sedangkan sanksi pidana merupakan the last resort (obat terakhir). Artinya, untuk meminimalisasi efek samping (side effect) dari hukum pidana, maka hukum pidana digunakan sebagai sarana terakhir di antara keseluruhan sarana hukum lain. Apabila sarana hukum lain tersebut gagal, maka hukum pidana harus diterapkan.

Uraian di atas diperkuat dengan pendapat yang dikemukakan oleh Modderman, ia mengatakan bahwa: "negara seyogyanya memidana hal-hal yang bertentangan dengan hukum yang tidak dapat dihambat oleh upayaupaya lain dengan baik". ${ }^{11}$ Dari pendapat ini jelas kiranya, jika upaya-upaya lain (sarana-sarana lain selain hukum pidana) lebih dikedepankan dibandingkan hukum pidana, dalam menanggulangi perbuatan-perbuatan yang bertentangan dengan hukum tidak berhasil, maka barulah hukum pidana diterapkan.

Sejalan dengan pendapat Barda Nawawi Arief bahwa: "usaha penanggulangan kejahatan dengan hukum pidana pada hakikatnya juga merupakan bagian dari usaha penegakan hukum (khususnya penegakan hukum pidana). Karena itu sering pula dikatakan bahwa kebijakan hukum pidana juga merupakan bagian dari kebijakan penegakan hukum (law enforcement policy)".

Bagi Bambang Waluyo, "penegakan hukum itu sendiri merupakan bagian tak terpisahkan dari pembangunan hukum dan sebagai komponen integral dari pembangunan nasional yang dilaksanakan dalam rangka menegakkan pilar-pilar negara hukum". ${ }^{13}$ Menurut Barda Nawawi Arif, "Pendekatan kebijakan integral mengandung arti : (i) ada keterpaduan (integralitas) antara politik kriminal dan politik sosial; (ii) ada

\footnotetext{
${ }^{10}$ Teguh Prasetyo, Politik Hukum Pidana., Op.Cit, hlm.8

${ }^{11}$ Ibid

${ }^{12}$ Barda Nawawi Arif, Bunga Rampai Kebijakan Hukum Pidana, Citra Aditya Bakti, Bandung, 2002, hlm. 29.

${ }^{13}$ Bambang Waluyo, Masalah Tindak Pidana dan Upaya Penegakan Hukum, Sumber Ilmu Jaya, 2006, Jakarta, hlm. 61.
} 
keterpaduan (intergralitas) antara upaya penanggulangan kejahatan dengan penal dan non penal". ${ }^{14}$

Masih menurut Barda, kebijakan integral dalam penanggulangan kejahatan mengandung konsekuensi bahwa: "segala usaha yang rasional untuk menanggulangi kejahatan harus merupakan satu kesatuan yang terpadu.Ini berarti kebijakan untuk menanggulangi kejahatan dengan menggunakan sanksi pidana, harus pula dipadukan dengan usaha-usaha lain yang bersifat non penal". ${ }^{15}$

Pendapat lain terkait perlu adanya kebijakan integral juga dikemukakan oleh Sudarto bahwa: "pengaruh dan kemampuan hukum pidana itu adalah terbatas, sehingga perlindungan masyarakat harus juga menggunakan sarana-sarana lain selain hukum pidana". ${ }^{16}$

Oleh karena kebijakan penanggulangan kejahatan yang merupakan bagian dari kebijakan sosial, dalam kerangka yang lebih besar merupakan kebijakan perencanaan pembangunan nasional, maka harus dilakukan secara rasional.

Menurut Samodra Wibawa, "pembuat kebijakan harus mengetahui berbagai hal yakni sebagai berikut : (i) preferensi nilai masyarakat dan kecenderungannya; (ii) pilihan-pilihan dan alternatif kebijakan yang tersedia; (iii) konsekuensi dari setiap pilihan kebijakan; (iv) rasio yang dicapai bagi setiap nilai yang dikorbankan pada setiap alternatif kebijakan; dan (v) memilih alternatif kebijakan yang paling efisien." 17

Berbagai hal tersebut di atas jelas menunjukkan bahwa suatu kebijakan penanggulangan kejahatan yang rasional tidak lain daripada penerapan metode-metode yang rasional.

Penegakan hukum itu dalam pandangan Satjipto Rahardjo, "selalu melibatkan manusia di dalamnya dan melibatkan juga tingkah laku manusia. Hukum tidak dapat tegak dengan sendirinya, artinya hukum tidak mampu mewujudkan sendiri janji-janji serta kehendakkehendak yang tercantum dalam (peraturan-peraturan) hukum". ${ }^{18}$

Dalam konteks ini, Barda menegaskan lebih lanjut bahwa: "hukum merupakan manifestasi dari nilai kepercayaan. Menegakkan wibawa hukum

${ }^{14}$ Barda Nawawi Arief, Bunga Rampai Kebijakan Hukum Pidana (Perkembangan Penyusunan Konsep KUHP Baru), Kencana, Jakarta, 2008, hlm. 3-4.

${ }^{15}$ Barda Nawawi Arief, Kebijakan Legislatif Dalam Penaggulangan Kejahatan Dengan Pidana Penjara, Badan Penerbit Universitas Diponegoro,Semarang 1996, hlm. 33.

${ }^{16}$ Sudarto, Hukum dan Hukum Pidana, Alumni,Bandung, 1977, hlm. 103.

${ }^{17}$ Samodra Wibawa, Kebijakan Publik Proses dan Analisis, Intermedia,Jakarta, 1994, hlm. 2.

${ }^{18}$ Satjipto Rahardjo, Penegakan Hukum Suatu Tinjauan Sosiologis, Cetakan II, Genta Publishing,Yogyakarta, 2011, hlm. 7. 
pada hakikatnya berarti menegakkan nilai kepercayaan di dalam masyarakat". ${ }^{19}$

Sebagai suatu proses yang bersifat sistemik, maka penegakan hukum pidana menampakkan diri sebagai penerapan hukum pidana (criminal law application) yang melibatkan pelbagai sub sistem struktural berupa aparat kepolisian, kejaksaan, pengadilan dan pemasyarakatan. Termasuk di dalamnya tentu saja lembaga penasehat hukum. Dalam hal ini Muladi mengatakan bahwa: "penerapan hukum haruslah dipandang dari 3 (tiga) dimensi, yaitu :

1. Penerapan hukum dipandang sebagai sistem normatif (normative system) yaitu penerapan keseluruhan aturan hukum yang menggambarkan nilai-nilai sosial yang didukung oleh sanksi pidana.

2. Penerapan hukum dipandang sebagai sistem administratif (administrative system) yang mencakup interaksi antara pelbagai aparatur penegak hukum yang merupakan sub sistem peradilan diatas.

3. Penerapan hukum pidana merupakan sistem sosial (social system), dalam arti bahwa dalam mendefinisikan tindak pidana harus pula diperhitungkan pelbagai perspektif pemikiran yang ada dalam lapisan masyarakat. Sehubungan dengan pelbagai dimensi di atas dapat diakatakan bahwa sebenarnya hasil penerapan hukum pidana harus menggambarkan keseluruhan hasil interaksi antara hukum, praktek administratif dan pelaku sosial.,"20

Bertolak dari pendekatan kebijakan itu pula, Sudarto berpendapat bahwa: "dalam kebijakan penegakan hukum dalam rangka penanggulangan kejahatan dengan menggunakan hukum pidana harus diperhatikan hal-hal sebagai berikut :

a. Penggunaan hukum pidana harus memperhatikan tujuan pembangunan nasional, yaitu mewujudkan masyarakat adil dan makmur yang merata materiel spiritual berdasarkan Pancasila; sehubungan dengan ini maka (penggunaan) hukum pidana bertujuan untuk menanggulangi kejahatan dan mengadakan pengugeran terhadap tindakan penanggulangan itu sendiri, demi kesejahteraan dan pengayoman masyarakat.

b. Perbuatan yang diusahakan untuk dicegah atau ditanggulangi dengan hukum pidana harus merupakan perbuatan yang tidak dikehendaki, yaitu perbuatan yang mendatangkan kerugian (material dan atau spiritual) atas warga masyarakat.

c. Penggunaan hukum pidana harus pula memperhitungkan prinsip biaya dan hasil.

d. Penggunaan hukum pidana harus pula memperhatikan kapasitas atau

${ }^{19}$ Barda Nawawi Arief, Masalah Penegakan Hukum dan Kebijakan Hukum Pidana Dalam Penanggulangan Kejahatan, Kencana, Jakarta, 2008, hlm. 22.

${ }^{20}$ Muladi, Kapita Selekta Sistem Peradilan Pidana, Badan Penerbit UNDIP,Semarang, 1995, hlm. 41. 
kemampuan daya kerja dari badan-badan penegak hukum, yaitu jangan sampai ada kelampauan beban tugas (overvelasting). ${ }^{21}$

Seperti yang telah dipaparkan dalam uraian sebelumnya, bahwa dunia pendidikan bukanlah dunia tanpa cela, atau dunia tanpa adanya penyimpangan (kejahatan). Menyitir pendapat Barda Nawawi Arief, bahwa: "perilaku menyimpang selalu ada pada tiap bentuk masyarakat, artinya tidak ada masyarakat yang sepi dari kejahatan". ${ }^{22}$ Fenomena kejahatan sebagai salah satu bentuk perilaku menyimpang akan selalu ada dan melekat pada tiap aspek kehidupan masyarakat tidak terkecuali pendidikan. B. S. Alper mengatakan bahwa: "kejahatan merupakan the oldest social problem atau masalah masyarakat yang tertua, sedangkan hukum pidana adalah the older philosophy on crime control, atau sarana penanggulangan kejahatan yang tertua". 23

Menuru Sudarto, sebagai salah satu sarana perlindungan masyarakat (social defence), dan sebagai the older philosophy of crime control, maka : "hukum pidana dapat digunakan untuk menanggulangi penyimpangan (tindak pidana) yang terjadi di setiap aspek kehidupan manusia. Jika hukum pidana hendak digunakan dalam mengatasi segi-segi negatif dari perkembangan masyarakat/modernisasi, maka hendaknya dilihat dalam hubungan keseluruhan politik kriminal atau social defence planning dan harus merupakan bagian integral dari rencana pembangunan nasional.,"24

Tindak Pidana di bidang pendidikan merupakan segi negatif dari perkembangan masyarakat di bidang pendidikan. Mengacu pada pendapat Sudarto di atas, jika hukum pidana hendak digunakan untuk menanggulangi tindak pidana di bidang pendidikan maka hukum pidana dalam hal ini dipandang sebagai bagian dari politik kriminal dan harus merupakan bagian integral dari pembangunan nasional, khususnya pembangunan di bidang pendidikan. Sudarto kemudian menegaskan bahwa: "penggunaan pidana terhadap suatu perbuatan harus memenuhi persyaratan sebagai berikut :

1. Penggunaan pidana harus memperhatikan tujuan pembangunan nasional, yaitu mewujudkan masyarakat adil dan makmur yang merata materiel spiritual berdasarkan Pancasila; sehubungan dengan ini maka (penggunaan) hukum pidana bertujuan untuk menanggulangi kejahatan dan mengadakan pengugeran terhadap tindakan penanggulangan itu sendiri, demi kesejahteraan dan pengayoman masyarakat.

2. Perbuatan yang diusahakan untuk dicegah atau ditanggulangi dengan hukum pidana harus merupakan perbuatan yang tidak dikehendaki,

\footnotetext{
21 Sudarto, Hukum dan Hukum Pidana, Alumni, Bandung, 1997, hlm. 44-48.

22 Barda Nawawi Arief, Kebijakan Legislatif...Loc.Cit.

23 Ibid, hlm 1 dan 18

${ }^{24}$ Muladi, Loc.Cit
} 
yaitu perbuatan yang mendatangkan kerugian (materiel dan atau spiritual) atas warga masyarakat.

3. Penggunaan hukum pidana harus pula memperhitungkan prinsip biaya dan hasil (cost and benefit principle).

4. Penggunaan hukum pidana harus pula memperhatikan kapasitas atau kemampuan daya kerja dari badan-badan penegak hukum, yaitu jangan sampai ada kelampauan beban tugas (overbelasting)."25

Penggunaan hukum pidana dalam ranah pendidikan ini seyogyanya harus memperhatikan dan memenuhi persyaratan atau prinsip-prinsip sebagaimana yang telah dikemukakan oleh para pemikir di atas, antara lain:

a. harus menggambarkan secara jelas tujuan yang hendak dicapai dari penggunaan hukum pidana dalam ranah pendidikan yakni "perlindungan pendidikan nasional", serta mengakomodir kepentingan yang lebih luas yang hendak dilindungi oleh hukum pidana itu sendiri;

b. hukum pidana diupayakan sebagai upaya yang terakhir (ultimum remedium) dari seluruh upaya penanggulangan yang ada (prinsip ultima ratio);

c. penyimpangan dalam pendidikan yang hendak dikrminalisasikan tersebut harus merupakan perbuatan yang benar-benar tidak dikehendaki oleh masyarakat;

d. penggunaan hukum pidana tersebut harus memperhatikan prinsip proporsionalitas (keseimbangan), yakni keseimbangan kerugian dan manfaat dari penggunaan hukum pidana tersebut, serta keseimbangan beban tugas dari aparat penegak hukum;

e. hukum pidana tersebut harus digunakan serasional mungkin (tepat dan teliti), dan humanistik. Hal ini sesuai dengan pendapat Herbert $L$. Parker bahwa: "hukum pidana akan menjadi penjamin utama (Prime Guarantor) apabila digunakan secara hemat dan cermat (providently), serta manusiawi (humanely)"

f. perumusan perbuatan yang hendak dikriminalisasikan harus jelas dan tegas (principle of differentiation);

g. hukum pidana tersebut harus mengakomodir kepentingan korban di dalamnya. ${ }^{26}$

Penanggulangan kejahatan tidak bisa hanya mengandalkan sarana penal karena hukum pidana dalam bekerjanya memiliki kelemahan/keterbatasan. Kelemahan/keterbatasan kemampuan hukum pidana dalam penanggulangan kejahatan telah banyak diungkapkan oleh para sarjana, antara lain:

1. Muladi menyatakan, bahwa "penegakan hukum pidana dalam kerangka sistem peradilan pidana tidak dapat diharapkan sebagai satu-satunya sarana penanggulangan kejahatan yang efektif,

\footnotetext{
25 Ibid. ,hlm 161

${ }^{26}$ Barda Nawawi Arief, Kumpulan Hand Out Kebijakan Hukum Pidana, hlm.41
} 
mengingat kemungkinan besar adanya pelaku-pelaku tindak pidana yang berada di luar kerangka proses peradilan pidana". ${ }^{27}$

2. Donald R. Taft dan Ralph W. England, sebagaimana dikutip oleh Barda Nawawi Arief, menyatakan bahwa "efektivitas hukum pidana tidak dapat diukur secara akurat. Hukum hanya merupakan salah satu sarana kontrol sosial. Kebiasaan, keyakinan agama, dukungan, dan pencelaan kelompok, penekanan dari kelompok-kelompok interest dan pengaruh dari pendapat umum merupakan sarana-sarana yang lebih efisien dalam mengatur tingkah laku manusia daripada sanksi hukum".28

3. Gustav Radbruch, sebagaimana dikutip oleh Laica Marzuki, mengingatkan bahwa "dalam produk perundang-undangan (gesetz) kadangkala terdapat Gezetzliches Unrecht, yakni ketidakadilan dalam undang-undang, sementara tidak sedikit ditemukan iibergesetzliches recht (keadilan di luar undang-undang) dalam kehidupan masyarakat".

4. Anwarul Yaqin, sebagaimana dikutip oleh Achmad Ali, mengemukakan bahwa "law plays only one regulates and influences human behaviour. Moral and social rules, though less explicit and less formal in their nature and content, also play a significant role in society's efforts to control behoviour". 29

Barda Nawawi Arief mengidentifikasikan sebab-sebab keterbatasan kemampuan hukum pidana dalam menanggulangi kejahatan sebagai berikut:

1. Sebab-sebab kejahatan yang demikian kompleks berada di luar jangkauan hukum pidana.

2. Hukum pidana hanya merupakan bagian kecil (sub sistem) dari saran kontrol sosial yang tidak mungkin mengatasi masalah kejahatan sebagai masalah kemanusiaan dan kemasyarakatan yang sangat kompleks (sebagai masalah sosio-psikologis, sosio-politik, sosio-ekonomi, sosio-kultural dan sebagainya);

3. Penggunaan hukum pidana dalam menganggulangi kejahatan hanya merupakan "kurrien am symptom" oleh karena itu hukum pidana hanya merupakan "pengobatan simptomatik" dan bukan "pengobatan kausatif"

4. Sanksi hukum pidana merupakan "remidium" yang mengandung sifat kontradiktif/paradoksal dan mengandung unsur-unsur serta efek samping negatif;

5. Sistem pemidanaan bersifat fragmentair dan individual/personal, tidak bersifat struktural/fungsional;

6. Keterbatasan jenis sanksi pidana dan sistem perumusan sanksi pidana yang bersifat kaku dan imperatif;

\footnotetext{
${ }^{27}$ Ibid., hlm. 18.

${ }^{28}$ Barda Nawawi Arief, Beberapa Aspek...Op.cit., hlm. 42.

${ }^{29}$ Achmad Ali, Menjelajahi Kajian Empiris Terhadap Hukum, Yarsif Watampone,
} Jakarta, 1998, hlm. 60. 
7. Bekerjanya/berfungsinya hukum pidana memerlukan sarana pendukung yang bervariasi dan lebih menuntut "biaya tinggi". ${ }^{30}$

Mengingat keterbatasan tersebut, maka "penggunaan sarana penal dalam menanggulangi kejahatan hendaknya dilakukan dengan melalui pertimbangan yang matang". ${ }^{31}$ Dalam menggunakan sarana penal, Nigel Walker pernah mengingatkan adanya "prinsip-prinsip pembatas" (the limiting principles) yang sepatutnya mendapat perhatian, antara lain :

1. Jangan hukum pidana digunakan semata-mata untuk tujuan pembalasan;

2. Jangan menggunakan hukum pidana untuk mepidana perbuatan yang tidak merugikan/membahayakan;

3. Jangan menggunakan hukum pidana untuk mencapai suatu tujuan yang dapat dicapai secara lebih efektif dengan sarana-sarana yang lebih ringan;

4. Jangan menggunakan hukum pidana apabila kerugian/bahaya yang timbul dari pidana lebih besar daripada kerugian/bahaya dari perbuatan/tindak pidana itu sendiri;

5. Larangan-larangan hukum pidana jangan mengandung sifat lebih berbahaya daripada perbuatan yang akan dicegah;

6. Hukum pidana jangan memuat larangan-larangan yang tidak mendapat dukungan kuat dari publik. ${ }^{32}$

Lebih lanjut Jeremy Bentham pernah menyatakan bahwa: "janganlah pidana dikenakan atau digunakan apabila "groundless, needless, unprofitable, or inneficacious". ${ }^{33}$ Herbert L. Pecker sebagaimana dikutip oleh Barda Nawawi Arief juga pernah mengingatkan bahwa "penggunaan sanksi pidana secara sembarangan/tidak pandang bulu/menyamaratakan (indiscriminately) dan digunakan secara paksa (coercively) akan menyebabkan pidana itu menjadi suatu "pengancam yang utama" (prime threatener)". ${ }^{34}$ Dari uraian di atas maka, penggunaan sarana penal dalam menanggulangi kejahatan khususnya di bidang pendidikan hendaknya dilakukan dengan penuh pertimbangan. Hal tersebut dilakukan mengingat dunia pendidikan memiliki karakteristik tersendiri yang harus didekati dengan pendekatan yang berbeda bila dibandingkan dengan pemberlakukan pidana pada kejahatan umumnya. Selain itu juga, perlu dipertimbangkan bahwa kebijakan hukum pidana termasuk kebijakan dalam penanggulangan kejahatan di bidang pendidikan merupakan bagian dari kebijakan sosial, kebijakan pembangunan nasional, bagian dari kebijakan kriminal yang juga merupakan bagian dari kebijakan penegakan hukum.

\footnotetext{
${ }^{30}$ Barda Nawawi Arief, Kebijakan Legislatif...op.cit., hlm. 46-47.

${ }^{31}$ Ibid, hlm.75

${ }^{32}$ Ibid.

${ }^{33} \mathrm{lbid}, \mathrm{hlm} .165$.

${ }^{34}$ Ibid.
} 
Pada sisi inilah penggunaan hukum pidana dalam penanggulangan kejahatan di bidang pendidikan yang dilakukan oleh guru ketika menjalankan profesi keguruannya menjadi signifikan. Signifikansi hukum pidana ini tidak diartikan harus melalui sarana penal dengan segala konsekuensi yang timbul didalamnya, namun pendekatan kebijakan hukum pidana yang rasional dalam mengatasi bentuk-bentuk kekerasan dalam dunia pendidikan terutama yang dilakukan oleh guru hendaknya didekati dengan pendekatan non penal yang lebih memberikan efek pemulihan sekaligus pembinaan terhadap guru yang melakukan kekerasan tersebut.

Hukum yang lengkap berisi norma dan sanksi, sudah termasuk peranan sanksi itu penting agar norma hukum itu efektif. ${ }^{35}$ Bagian penting dari hukum pidana yang masih kurang mendapat perhatian pada bagian mengenai "pemidanaan" (sentencing atau straftoemeing") sangat penting karena akan berpuncak pada pemidanaan yang dapat merengut kemerdekaan seseorang, harta benda, bahkan jiwanya.

Ahli kriminologi terkenal N.Morris and G.Hawkins dari Amerika Serikat mengatakan pemidanaan merupakan bagian dari hukum Pidana yang begitu sewenang-wenang atau tidak mempunyai prinsip. ("...no branch of criminal law is more unprincipled or more anarchical"). Berdasarkan penelitiannya tentang Undang-undang Hukum Pidana dan pemidanaan ternyata tidak mempunyai pedoman dan prinsip yang jelas, sehingga hakim pidana akan sulit melaksanakan tugasnya dengan baik, yang berakibat timbul praktekpraktek pemidanaan di pengadilan yang terkesan sewenangwenang. ${ }^{36}$

Agar terkesan tidak sewenang-wenang dalam proses pemidanaan ditentukan tersangka bersalah atau tidak maka aparat penegak hukum harus menyelidiki apakah perbuatan tersangka tersebut sudah melawan hukum atau tidak.

Pemidanaan bukan merupakan hal yang menyenangkan bagi seseorang yang dipidana. Pemidanaan juga menghabiskan biaya yang relatif banyak, misalnya dalam biaya proses dalam pengadilan, penjara, pembebasan bersyarat, pusat-pusat konsultasi yang harus dihadiri, dan pengumpulan denda. ${ }^{37}$

Menurut teori utilitarian yang dikemukakan Bentham, pemidanaan merupakan kejahatan (mischief) yang hanya dapat dijustifikasi jika

\footnotetext{
${ }^{35}$ Oce Salman, Ikhtisar Filsafat Hukum, Armico,Bandung, hlm. 51-52.

${ }^{36}$ Tina Asmarawati, Pidana Dan Pemidanaan Dalam Sistem Hukum Di Indonesia Deepublish,Yogyakarta, 2014, hlm. 135.

${ }^{37}$ Syaiful Bakhri, Kebijakan Kriminal Dalam Perspektif Pembaruan Sistem Peradilan Pidana Indonesia, Total Media, Jakarta, 2010, hlm. 57.
} 
kejahatan tersebut mampu menjegah terjadinya kejahatan yang lebih besar dibandingkan dengan pemidanaan bagi pelaku kejahatan. ${ }^{38}$

Pasal 39 ayat (2), Undang-undang Nomor 20 Tahun 2003 tentang Sistem Pendidikan Nasional menyebutkan bahwa tugas utama seorang Guru adalah dalam proses pembelajaran, pembimbingan dan pelatihan; sedangkan untuk pendidik pada perguruan tinggi diperluas dengan tugas di bidang penelitian dan pengabdian masyarakat. ${ }^{39}$ Dari rumusan pasal di atas, Barda Nawawi Arief menyimpulkan bahwa: "perlindungan guru dalam menjalankan profesinya tersebut terkait erat dengan tugasnya sebagai pendidik. ${ }^{40}$

Sejak disahkannya Undang-undang Guru dan Dosen pada tanggal 06 Desember 2005, ketentuan Pasal 39 ayat (2) di atas dipertegas dengan ketentuan Pasal 1 huruf a Undang-undang Guru dan Dosen, yang berbunyi sebagai berikut: "Guru adalah pendidik profesional dengan tugas utama mendidik, mengajar, membimbing, mengarahkan, melatih, menilai, dan mengevaluasi peserta didik pada pendidikan anak usia dini jalur pendidikan formal, pendidikan dasar, dan pendidikan menengah".

Perlindungan profesi guru dari tindakan tercela guru itu sendiri (dalam hal ini guru sebagai pelaku (subjek) tindak pidana terkait erat dengan tugasnya sebagai pendidik. Dalam menjalankan tugasnya, tidak jarang guru menerapkan kebijaksanaan pendidikan yang dirasakan berat oleh murid (peserta didik), bahkan merugikan murid seperti halnya pemberian hukuman (tindakan disiplin) yang mengandung unsur kekerasan fisik. Fenomena yang terjadi dewasa ini tidak sekedar tindakan kedisiplinan, namun telah mengarah pada tindak pidana murni, misalnya penganiayaan. Dilihat dari aspek hukum pidana, mungkin saja perbuatan/tindakan guru yang dikemukakan diatas, secara formal bersifat melawan hukum atau merupakan tindak pidana. Misalnya, dapat dikategorikan sebagai bentuk "penghinaan" (Pasal 310/315 KUHP); "perampasan kemerdekaan" (Pasal 333-334 KUHP); "perbuatan tidak menyenangkan” (Pasal 335 KUHP), atau sebagai bentuk "penganiayaan” (Pasal 351 dan Pasal 352 KUHP).

Meskipun demikian, penetrasi hukum pidana dalam ranah pendidikan untuk beberapa kalangan masih dianggap sebagai sesuatu yang berlebihan. Dikatakan demikian karena hukum pidana dan pendidikan mempunyai sifat dan pendekatan yang berbeda dalam menanggulangi suatu penyimpangan. Hukum pidana bersifat keras dan tegas karena dilengkapi dengan sanksi pidana dalam penerapannya, sedangkan pendidikan bersifat lunak karena lebih mengedepankan pendekatan kognitif, afektif dan psikomotorik secara integral dalam pembinaannya. Nasional

${ }^{38}$ Ibid

${ }^{39}$ Pasal 39 ayat (2), Undang-undang Nomor 20 Tahun 2003 tentang Sistem Pendidikan

${ }^{40}$ Barda Nawawi Arief, Makalah "Perlindungan Profesi Guru Dari Aspek Hukum Pidana, Op.cit., hlm. 3. 
Dalam sistem peradilan pidana pemidaan itu bukanlah merupakan tujuan akhir dan bukan pula merupakan satu - satunya cara untuk mencapai tujuan pidana atau tujuan sistem peradilan pidana. Banyak cara dapat ditempuh, dapat menggunakan hukum pidana maupun dengan cara diluar hukum pidana atau diluar pengadilan. Dilihat dari segi ekonomisnya sistem peradilan pidana disamping tidak efisien, juga pidana penjara yang tidak benar - benar diperlukan semestinya tidak usah diterapkan.

Pencegahan kejahatan harus mampu memandang realitas sosial masyarakat, hukum sebagai panglima harus mampu menciptakan suatu tatanan sosial melalui kebijakan sosial. Optimalisasi jalur non penal sejalan dengan cita-cita bangsa dan tujuan negara, seperti yang tercantum dalam Pembukaan Undang-Undang Dasar Republik Indonesia Tahun 1945 yang memuat Pancasila. Segala bentuk pembangunan harus berangkat dari nilainilai Pancasila, karena pada hakikatnya pancasila merupakan tonggak konvergensi berbagai gagasan dan pemikiran mengenai dasar falsafah kenegaraan yang didiskusikan secara mendalam oleh para pendiri negara. Pancasila menjadi kesepakatan luhur (modus vivendi) yang kemudian ditetapkan sebagai dasar ideologi negara. Dalam hal ini, upaya non penal dalam pencegahan tindak pidana merupakan salah satu aspek cita-cita Pancasila, Pancasila menjadi dasar rasional mengenai asumsi tentang hukum yang akan dibangun sekaligus sebagai orientasi yang menunjukan kemana bangsa dan negara harus dibangun.

Menurut Jimly Asshidiqie bahwa: "Perbuatan melawan hukum yang dilakukan oleh guru ternyata tidak selalu diselesaikan melalui jalan penal akan tetapi bisa diselesaikan melalui jalan Non penal yaitu penyelesaian sengketa di luar mekanisme pengadilan melalui mekanisme mediasi dan arbitrase." 41

Senada dengan pendapat Jimly Asshidiqie disisi lain pemikiran tentang pembaharuan hukum pidana sebagaimana diungkapkan oleh Barda Nawawi Arief, mengatakan bahwa: "dalam hukum pidana tidak selalu orang yang secara formal telah melakukan perbuatan melawan hukum (tindak pidana) harus dipertanggungjawabkan atau dipidana. dalam hukum pidana ada "Alasan Penghapus Pidana (APP) berupa 'alasan pembenar' (yang menghapuskan sifat melawan hukumnya perbuatan) dan 'alasan pemaaf' (menghapuskan kesalahan). APP dapat berdasarkan ketentuan undang-undang (APP formil) dan berdasarkan ketentuan hukum tidak tertulis (APP materiel)." ${ }^{42}$

Lebih lanjut Barda Nawawi mengatakan, bahwa: "dalam APP materiel dikenal antara lain dua asas yang sangat popular dan fundamental, yaitu: Asas "tidak adanya sifat melawan hukum secara materiel (dikenal dengan asas

41 Jimly Asshidiqie, Peradilan Etik dan Etika Konstitusi, Sinar Grafika,Jakarta, 2014, hlm 22.

42 Barda Nawawi Arief, Pembaruan Hukum Pidana dalam Perspektif Kajian Perbandingan" PT Citra Aditya Bakti, Bandung, 2011, hlm. 74. 
"materiele wederrechtelijkheid" atau asas AVAW - "Afwezigheid van Alle Materiele Wederrechtelijkheid"). Asas "tidak adanya kesalahan sama sekali" (dikenal dengan asas "green straf zonder schuld" atau asa AVAS "Afwezigheid van Alle Schuld"). ${ }^{43}$

Dengan adanya asas atau doktrin "sifat melawan hukum materiel", maka suatu perbuatan yang secara formil bersifat melawan hukum menurut Barda Nawawi Arief dapat dinyatakan sebagai "bukan tindak pidana" apabila perbuatannya itu secara materiel tidak bersifat melawan hukum. ${ }^{44}$ Barda Nawawi selanjutnya mengatakan bahwa: "penilaian, apakah suatu perbuatan itu tidak bersifat melawan secara materiel, dapat didasarkan pada nilai yang ada dalam kehidupan (norma) sosial, norma kebudayaan (culture norm), nilainilai kesusilaan dan kepatutan masyarakat, tujuan ketertiban hukum, asasasas hukum umum dan hukum tidak tertulis yang diakui dalam masyarakat maupun dalam profesi tertentu (termasuk hukum disiplin, "tuchtrecht", dalam profesi guru), dan bahkan hukum tidak tertulis yang diakui dalam bidang keilmuan dan masyarakat bangsa-bangsa." 45

Dengan demikian, apabila perbuatan/tindakan/kebijaksanaan guru dalam melaksanakan tugas profesionalnya sesuai dengan kriteria/ramburambu materiel di atas, maka perbuatannya itu dapat dinyatakan tidak bersifat melawan hukum secara materiel. 


\section{Kesimpulan :}

Pertama, Kebijakan hukum pidana saat ini untuk menanggulangi tindak pidana di bidang pendidikan, khususnya terhadap tindak pidana yang dilakukan guru dalam melaksanakan tugasnya, diatur dalam KUHP dan Undang-undang Nomor 35 Tahun 2014 tentang Perlindungan Anak. Ketentuan dalam kedua undang-undang tersebut meliputi perihal penganiayaan, yakni Pasal 351, 352, 353, 354, 355 KUHP, Pasal 80 Undang-undang 23 Tahun 2002, perampasan kemerdekaan, yakni Pasal 333 dan 334 KUHP, penghinaan dan pencemaran nama baik, yakni Pasal 310 ayat (1) dan 315 KUHP, perbuatan tidak menyenangkan, yakni Pasal 335 KUHP, dan pelecehan seksual, diatur dalam Pasal 287 ayat (1) dan 294 KUHP, Pasal 81 ayat (1) dan 82 Undangundang Nomor 35 Tahun 2014.

Kedua, Penegakan hukum dengan sarana penal merupakan salah satu aspek saja dari usaha masyarakat menanggulangi kejahatan. Disamping itu masih dikenal usaha masyarakat menanggulangi kejahatan melalui sarana non penal. Usaha non penal dalam menanggulangi kejahatan sangat berkaitan erat dengan usaha penal. Upaya non penal ini dengan sendirinya akan sangat efektif menunjang penyelenggaraan peradilan pidana dalam mencapai tujuannya. Pencegahan atau menanggulangi kejahatan harus dilakukan pendekatan integral yaitu antara sarana penal dan non penal.

\section{Saran :}

Pertama, Kepada lembaga penegak hukum, hendaknya memiliki paradigma yang sama dalam upaya menanggulangi kejahatan yang dilakukan guru dalam menjalankan profesinya dengan penuh pertimbangan dan lebih mengedepankan upaya-upaya non penal. Kepada pemerintah agar selalu berupaya untuk menghadirkan perlindungan hukum bagi guru juga untuk siswa/siswinya sehingga keberlangsungan dunia pendidikan tetap terjaga dengan baik dengan mempertimbangkan aspek sosial masyarakat.

Kedua, kepada lembaga pendidikan harus melakukan upaya preventif di dalam melakukan kebijakan terhadap penanganan tidak pidana terutama kepada siswa/siswa yang sering kali menjadi objek pelaku tindak pidana di sekolah. Demikian juga halnya antara siswa/siswi antar sekolah juga bagian yang tidak terpisahkan, bagaimana upaya yang dilakukan pemerintah harus sinergis dengan para pemangku kepentingan disekolah tersebut. 


\section{Daftar Pustaka}

Achmad Ali, Menjelajahi Kajian Empiris Terhadap Hukum, Yarsif Watampone, Jakarta, 1998.

Bambang Waluyo, Masalah Tindak Pidana dan Upaya Penegakan Hukum, Sumber Ilmu Jaya, Jakarta, 2006.

Barda Nawawi Arief, Pembaruan Hukum Pidana dalam Perspektif Kajian Perbandingan” PT Citra Aditya Bakti, Bandung, 2011.

-.-. Bunga Rampai Kebijakan Hukum Pidana, Citra Aditya Bakti,Bandung, 2002.

- Kebijakan Legislatif Dalam Penanggulangan Kejahatan Dengan Pidana Penjara,Badan Penerbit UNDIP, Semarang, 1996.

Bunga Rampai Kebijakan Hukum Pidana (Perkembangan Penyusunan Konsep KUHP Baru), Kencana,Jakarta, 2008.

Masalah Penegakan Hukum dan Kebijakan Hukum Pidana Dalam Penanggulangan Kejahatan,Kencana, Jakarta, 2008.

JimlyAsshiddiqie, Peradilan Etik dan Etika Konstitusi,Sinar Grafika, Jakarta, 2014.

Muladi, Kapita Selekta Sistem Peradilan Pidana, Badan Penerbit UNDIP, Semarang, 1995.

Oce Salman, Ikhtisar Filsafat Hukum, Bandung, Armico

Ridwan Halim, Tindak Pidana Pendidikan Dalam Asas-Asas Hukum Pidana Indonesia, Ghalia Indonesia, Jakarta, 1986.

Samodra Wibawa, Kebijakan Publik Proses dan Analisis, Intermedia, Jakarta,1994.

Satjipto Rahardjo, Penegakan Hukum Suatu Tinjauan Sosiologis, Cetakan II, Genta Publishing,Yogyakarta, 2011.

Sudarto, Hukum dan Hukum Pidana, Alumni,Bandung, 1977.

Syaiful Bakhri, Kebijakan Kriminal Dalam Perspektif Pembaruan Sistem Peradilan Pidana Indonesia, Total Media, Jakarta, 2010.

Tina Asmarawati, Pidana Dan Pemidanaan Dalam Sistem Hukum Di Indonesia Deepublish, Yogyakarta, 2014. 